\title{
Japanese National Railways' Financing Schemes and Bankruptcy
}

\author{
Nobuo TAKAHASHI ${ }^{\text {a) }}$
}

\begin{abstract}
Japan's prewar railroad business (Ministry of Transport) was transferred to a public corporation, Japanese National Railways (JNR), after World War II and eventually went bankrupt. This was due to a number of factors, including the decline in the position of railroads, ballooning personnel costs, and the existence of unprofitable local lines. However, the issue that directly caused the crash was the failure of the financing scheme that formed part of the company's third long-term plan, which commenced in FY 1965. The company had not taken government subsidies or increased its borrowings from the Fiscal Investment and Loan Program (FILP), but instead went outside the FILP and issued large volumes of high-interest rate tokubetsu (special) bonds without a government guarantee, so that by FY 1967, interest and debt-related expenses totaled 101.2 billion yen, or about the same as the 104 billion yen raised by tokubetsu bonds. In other words, tokubetsu bonds were being issued to finance the payment of interest on railway bonds. As a result, the company went bankrupt in the first few years of its seven-year plan, which changed into a financial rehabilitation plan starting in $F Y$ 1969.
\end{abstract}

a) Graduate School of Economics, University of Tokyo, 7-3-1 Hongo, Bunkyo-ku, Tokyo, Japan, nobuta@e.u-tokyo.ac.jp

A version of this paper was presented at the ABAS Conference 2019 Autumn (Takahashi, 2019).

(C) 2019 Nobuo Takahashi. This is an Open Access article distributed under the terms of the Creative Commons Attribution License, which permits unrestricted reuse, distribution, and reproduction in any medium, provided the original work is properly cited. 
Keywords: Japanese National Railways (JNR), bankruptcy, financing scheme, the third long-term plan

\section{Introduction}

The post-war reform of the government railways began in July 1948, when the Japanese government received General MacArthur's letter from the occupation forces' General Headquarters (GHQ) calling for the prohibition of strikes by public servants and reorganization of the government railways and other major government enterprises into public corporations (Imashiro, 1988, p. 201). In June 1949, the Railway Board of the Ministry of Transportation, which had been operating as a business in the state's special accounts until then, was transferred to a public corporation called Japanese National Railways (Nihon Kokuyu Tetsudo, JNR) (Aoki, Imashiro, Kato, \& Wakuda, 2000, p. 121). JNR did reasonably well until the early 1960 s, but it went into the red in FY 1964, when the Tokaido Shinkansen (bullet train), the first of its kind in the world, started operating (Kikuchi, 2016, 2018), and JNR's operations deteriorated from then on. Starting in the late 1970s, the Board of Audit of Japan, which was concerned about the situation, wrote special descriptions of JNR's operating conditions (A, B) and proposed measures to improve the situation (C, D, and E) (Takahashi, 2000, 2001).

A) JNR profit and loss (FY 1976 Audit Report, pp. 194-196, special description)

B) Construction conditions, operating conditions, and facilities investment effects, etc., for administrative improvement (FY 1977 Audit Report, pp. 229-240, special description)

C) Freight business (FY 1980 Audit Report, pp. 167-175, special 
description)

D) Baggage business (FY 1981 Audit Report, pp. 180-188, special description)

E) Passenger transportation business, etc. (FY 1982 Audit Report, pp. 240-254, special description)

Special description A) began with the following sentence.

JNR has lost money every year since FY 1964, and its loss carryforwards as of the end of FY 1975 far exceeded its combined capital and reserves. As a step toward its financial rehabilitation, the Japanese National Railways Act was amended in November 1976 to move 2,540,405 million yen of the company's long-term debt, as of the end of the prior fiscal year, into a special account for the disposition of certain obligations. It received non-interest-bearing loans $(59,083$ million yen in FY 1976) and interest subsidies (about 184,992.98 million yen in FY 1976) from the general account, and principal and interest payments were equalized for 20 years, among other measures. In addition, the $37 \%$ real increase in fares and charges planned for that month was delayed by five months from the initial plan.

Unfortunately, however, the net loss for the year was about the same as that of the previous year. Passenger revenues of about $1,529,024.23$ million yen and freight revenues of about 277,928.06 million yen constituted $90.1 \%$ of revenues, but despite the hike in fares and charges, traffic volumes declined by 4.6 billion passenger-km (2.1\%) for passengers and 1.0 billion ton-km $(2.3 \%)$ for freight. Passenger revenues therefore rose by only about $213,898.86$ million yen (16.2\%) and freight revenues rose by only about $36,381.34$ million yen (15.0\%) over the prior year. At the same time, personnel costs went up by some $157,109.6$ million yen from the prior year due to such factors as increases in salaries. Thus, despite increasing fares and charges and taking various financial measures, 
the company had a huge net loss in its general account, and it concluded, "We recognize that it will be difficult to return to break-even" by the target year of FY 1979.

The cause of JNR's bankruptcy has usually been attributed to the decline in the popularity of railroads, bloated personnel costs, and the operation of too many unprofitable local lines during the 1970s. However, these were not really the direct causes of the bankruptcy. The direct cause of the bankruptcy was the failure of the third long-term plan's financing scheme, which was launched in 1965 (Takahashi, 2000). The third long-term plan that began in FY 1965 was supposed to be a seven-year plan, but the company failed within a few years, and in FY 1969, the plan had to be converted into a financial rehabilitation plan.

\section{A Scenario for Bankruptcy}

JNR had a bright future around the time that the third long-term plan was launched. The Tokaido Shinkansen, which began operating in 1964, drew worldwide attention, and "the word shinkansen even became synonymous with high-speed train in English language" (Aoki et al., 2000, p. 181). In a state of euphoria, JNR loudly proclaimed a bright future, saying, "Never have so many people been so excited by our third long-term plan" (Ichijo \& Ishikawa, 1966, p. 3).

In actuality, in the wake of the Mikawajima accident in May 1962 (160 dead) and the Tsurumi accident in November 1963 (161 dead), "Public opinion was overwhelmingly critical of JNR's overcrowded schedule" (Ichijo \& Ishikawa, 1966, p. 44). The reason for such tight scheduling was that many track segments ran both commuter trains and medium/long-distance trains. It was thus necessary to improve track to alleviate the crowding in the Tokyo and Osaka schedules. Hence, the third long-term plan was born. 
However, when the third long-term plan was being formulated, JNR Advisory Committee submitted a report titled "How JNR Should Be Managed," to the JNR President on May 10, 1963, in which it did trial calculations on what would happen to the company by FY 1970 and warned of a "total collapse" due to debt maturities and interest payments. Based on assumptions that "future transportation demand would be satisfactory but not enough, fares and other conditions would be kept at the current levels or the current trend," by FY 1970, (a) a mammoth corporation with annual revenues of 818.9 billion yen (b) would only have 7.2 billion yen left after paying its operating expenses and the interest on its debt. Even so, (c) the company needed to make new investments of 330 billion yen every year, which would require it to borrow huge sums of money year after year. As a result, (d) debt outstanding would balloon to 2.4 trillion yen, thus concluding, "A total collapse is inevitable" (Nihon Kokuyu Tetsudo [Kokutetsu], 1973, p. 161). In the actual FY 1970 financial report (FY 1970 JNR Audit Report), although revenues rose due to a fare hike, debt was about the same as had been predicted, at 2,603.7 billion yen.

In fact, this trial calculation had been based on the outcome of funding 330 billion yen of annual new investments with interest-bearing financing. JNR's funding of capital investments was actually about the same as in the scenario: for the three years starting in FY 1965, the company raised 326.6 billion yen, 330.4 billion yen, and 363.4 billion yen. If the company was unable to pay even its interest because it was already in a tight financial position similar to that in (b), it would fall into the vicious circle of having to borrow more funds to pay its interest, which would cause its debt to snowball further. Even without considering the reality of railway management, the mere failure of this financing scheme fulfilled the scenario of "total collapse" as a result of debt maturities and interest payments. 
To prevent this scenario, the third long-term plan was deliberated by the majority party's JNR Key Issues Research Committee and the Government's JNR Key Issues Study Group, and up through the second five-year plan, the long-term plans were formulated solely by JNR. As a government economic ministers' round-table conference in December 1964 acknowledged, "The government has decided to implement JNR's new long-term plan for the seven-year period from FY 1965 through FY 1971, which calls for investments of approximately 2.9 trillion yen" (FY 1964 JNR Audit Report, p. 133). So, the plan should have been put into action after receiving Cabinet approval in January 1964 (Kokutetsu, 1973, p. 646).

However, when JNR applied to the Fiscal Investment and Loan Program (FILP) for a large-scale increase when it submitted its budget for FY 1965, year one of the third long-term plan, the Ministry of Finance expressed disapproval, so the funds were raised by issuing railway bonds without a government guarantee, i.e., tokubetsu (special) bonds (Kokutetsu, 1973, pp. 688-691). Thus, JNR did not receive any government subsidies or increased funding from FILP but instead issued large volumes of tokubetsu bonds outside FILP's scope that had higher interest rates than if they had been guaranteed by the government, and in FY 1967, its funding costs had reached an annual rate of $7.1 \%$.

Thus, the third long-term plan, which was supposed to be a seven-year plan, failed within a few years, and the Act on Special Measures for Promoting Reconstruction of the Japanese National Railways was passed in 1969. This consisted of such fiscal measures as the virtual suspension of interest payments on its government-managed debt during the rehabilitation period at the end of FY 1968, and the long-term plan changed into a financial rehabilitation plan from FY 1969. 


\section{The Failure of Financing Schemes}

JNR's long-term financing scheme consisted of bank loans and bonds (railway bonds), which were funded by FILP funds and private-sector money. Here, FILP refers to the government's investment and loan program that provides various public funds backed by the government's full faith and credit and that furnishes interest-bearing financing to be repaid with interest. FILP's funding consists of the following four financial sources (Finance Bureau, Ministry of Finance, 1993, Chapter 1).

A) Funds from the Trust Fund Bureau (postal savings, funds from the Employees' Pension Insurance and National Pension Insurance systems, other funds, reserve funds, and surplus funds from the Foreign Exchange Funds Special Account and other special accounts of the government)

B) Postal life insurance funds (funds gathered through the postal life insurance program)

C) Industrial investment special accounts (including payments to the national treasury from the Japan Export-Import Bank and the Japan Development Bank and funds transferred from the General Account up through FY 1980)

D) Government-guaranteed bonds / Government-guaranteed borrowings

Of these, D) government-guaranteed bonds and governmentguaranteed borrowings consist of bonds and borrowings that are guaranteed by the government within the scope of its budget. Although the funding comes from the private sector (not from FILP funds), it is treated as part of FILP. When an investing institution like JNR gets financing from the private sector, the Government's General Account will guarantee repayment of the principal and the debt's creditworthiness is enhanced by the 
government's general involvement in negotiating the funding amount, issuance terms, etc. In fact, until 1964, most of JNR's capital funding was provided by FILP. However, issuance of tokubetsu bonds commenced in FY 1965, the first year of the third long-term plan, so reliance on FILP declined (Figure 1). The reason for the sudden decline in reliance on FILP was that the scale of fund-raising for capital funding, which had never before reached even 180 billion yen per year, suddenly jumped by an additional 100 billion yen from tokubetsu bonds issued outside the FILP framework, as shown in Figure 2.

Thus, government subsidies and additional FILP funding were passed by, and large volumes of tokubetsu bonds with higher interest rates than those guaranteed by the government were issued outside the FILP, so that in FY 1967, funding rates increased to $7.1 \%$ per annum and interest payments had gone up 10-fold over their level in FY 1955. We can see the gravity of the situation when we consider that passenger revenues grew 4.4-fold and freight revenues doubled over the same period (Kokutetsu, 1973, pp. 162-163, p. 167). As a

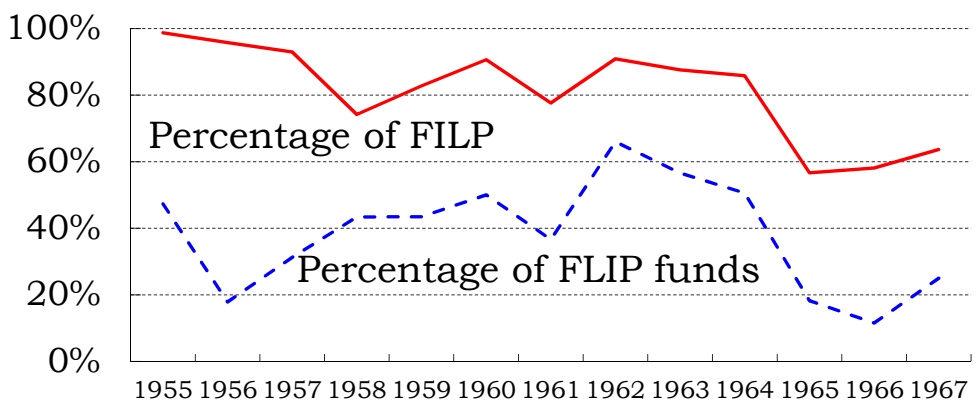

Figure 1. Percentage of FILP to JNR's capital expenditure (in fiscal years)

Source: Takahashi (2000, Figure 1-1). 


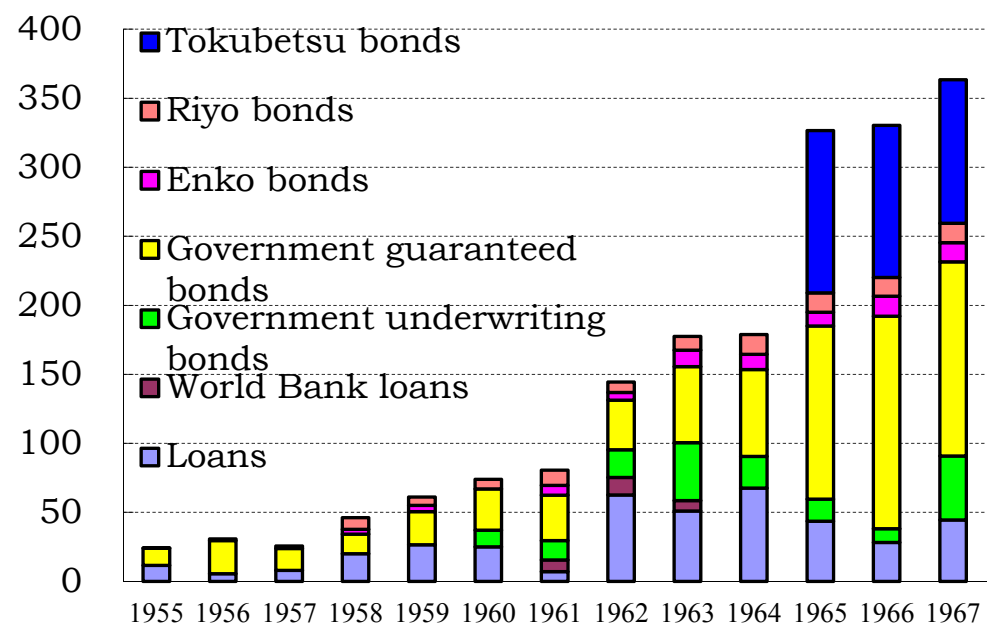

Figure 2. Capital financing from outside JNR (in fiscal years) Source: Takahashi (2000, Figure 1-2).

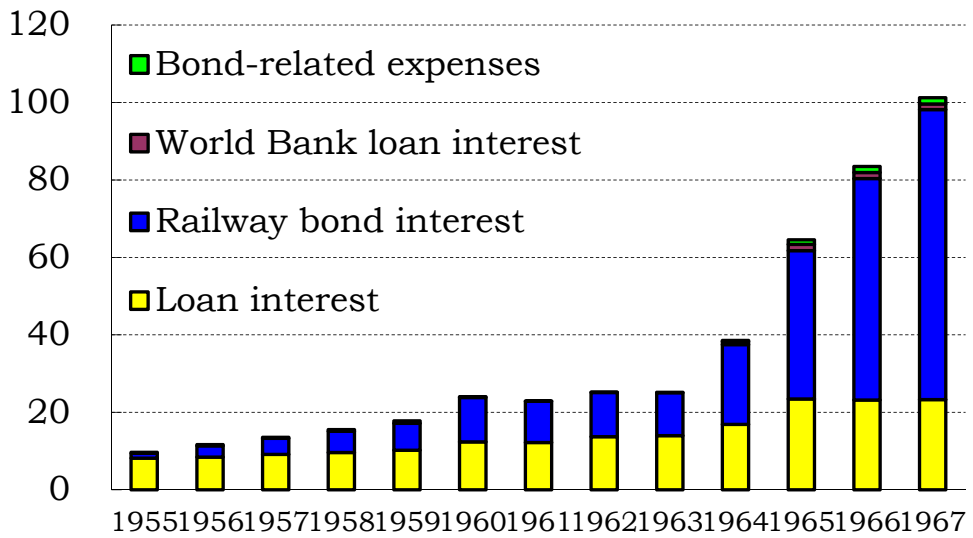

Figure 3. Trends in JNR's interest and debt handling expenses (in fiscal years)

Source: Takahashi (2000, Figure 1-3). 
result, interest and debt-related expenses jumped, totaling 101.2 billion yen in FY 1967, which was almost equivalent to the 104 billion yen raised through the tokubetsu bonds. Moreover, as we can see from Figure 3, most of the increase in the skyrocketing interest and debt-related expenses was due to interest on railway bonds. In other words, two years after JNR started issuing tokubetsu bonds, JNR had already fallen into the situation in which it was issuing tokubetsu bonds to meet the interest payments on its railway bonds.

\section{Discussion}

At the end of FY 1968, JNR started to receive assistance in the form of "construction subsidies" to subsidize its losses under the financial rehabilitation plan starting in FY 1969. Before that, JNR was supplementing its construction costs by floating public bonds and using its earnings to pay for improvements (Nakamura, 2019). However, the third long-term plan adopted a financing scheme covering improvement costs with borrowings and bonds. So why didn't JNR set aside earnings, or internal reserves, to cover the necessary improvement costs in its upgrade construction and equipment updates? Stated bluntly, the answer is that the government and local governments were not respecting JNR's financial independence but were milking it of money.

The government made JNR take over the costs of its social, educational, and industrial policies, so that from its founding in FY 1949 through FY 1967, JNR had shouldered 951.4 billion yen in expenses, consisting of 742.4 billion yen in passenger fares (including 691.5 billion yen from commuter and school passes), 157.8 billion from freight, and 51.2 billion yen from special newspapers and magazines (Kokutetsu, 1973, pp. 170-172). In addition, local governments took 99.7 billion yen of municipal levies from JNR between FY 1956 and FY 1967, based on the Act 
Concerning Grants and Levies on State Assets, etc., Located in Municipalities (Kokutetsu, 1973, pp. 170-172). In short, funds totaling 1,051.1 billion yen were lifted from JNR by the national and local governments. This is almost equivalent to the $1,020.4$ billion yen ( $=326.6$ billion yen +330.4 billion yen +363.4 billion yen) that had been raised by JNR in the form of interest-bearing debt in the first three years of its seven-year third long-term plan.

Furthermore, while privately owned railway companies were periodically raising their fares in line with inflation, JNR's fares were kept down by the government as an anti-inflationary measure, which was a mistake. The Public Finance Act enacted in 1947 stipulated that JNR's fares were to be determined by law or by a resolution of the National Diet. In fact, the JNR Fare Act was enacted the following year, in 1948, so that the basic charges for passengers and freight were statutory. These harsh fare regulations remained in place until the end of 1977, when the Diet resolution requirement was changed to government approval, as long as the fare increase remained within the scope of the expected increase in expenses from inflation (Nakanishi, 1988, pp. 311-312). This undoubtedly interfered with JNR's ability to retain adequate capital reserves. In fact, in the 1940s and 1950s, JNR fares were frozen as a way to fight inflation, and even in the case of the fare hike of March 1966, although JNR had requested a $37 \%$ increase in passenger fares with a $15 \%$ increase in freight charges to help fund its third long-term plan starting in FY 1965, the request has been shelved for a year, after which the passenger fare hike was cut back to $31.2 \%$ and the increase in freight charges was limited to $12.3 \%$ (Nakanishi, 1988, p. 322).

\section{Conclusion}

To go bankrupt in line with one's own crisis scenario is very foolish. Still, the Japanese people have now forgotten the lessons of 
JNR as an era of extremely low interest rates has prevailed for several decades. We must not forget that railroad construction and the railroad business is a contest with interest payments. Back in December 1989, the Cabinet decision laying out the steps to be taken to repay the debt of the JNR Settlement Corporation stated, "Disposition of the corporation's debts is, in other words, a contest with interest rates." However, the subsequent increase in the corporation's debts shows that the corporation's revenues from asset dispositions ultimately lost the contest with interest payments on the debt principal (Ishido, 1999).

After JNR was privatized and broken up in 1987, the East Japan Railway Company (JR East) was able to skillfully navigate the winds of the low-interest period, raising long-term financing by converting high-cost debt into low-cost debt. As a result, it succeeded in lowering the nominal interest rate on its long-term debt from $7.13 \%$ at the beginning of FY 1987, when it was founded, to $4.62 \%$ at the end of FY 1998. If the company were to fall into a situation where its interest payments ate up its operating income, like JNR from the 1970s onward, it would not be able to do anything operationally, and before one knows it, the business efforts themselves would probably be forgotten (Takahashi, 2000).

\section{Acknowledgments}

This work was supported by JSPS KAKENHI Grant Number JP19K01857 for FY 2019-2023 and JSPS Grant-in-Aid for Publication of Scientific Research Results, Grant Number JP16HP2004.

\section{References}

Aoki, E., Imashiro, M., Kato, S., \& Wakuda, Y. (2000). A history of 
Japanese railways 1872-1999. Tokyo, Japan: East Japan Railway Culture Foundation.

Finance Bureau, Ministry of Finance (Ed.). (1993). Zaisei to yushi handobukku [Handbook of fiscal investment and loan program]. Tokyo, Japan: Ministry of Finance Printing Bureau (in Japanese).

Ichijo, Y., \& Ishikawa, T. (1966). Kokutetsu wa kawaru: Mirai ni idomu choki keikaku [JNR changes: A long-term plan for the future]. Tokyo, Japan: Shiseido (in Japanese).

Imashiro, M. (1988). Sengo no Kokutetsu: 1946-1963 [Post-war Japanese National Railways: 1946-1963]. In Transportation Economics Research Center (Ed.), Tetsudo seisaku-ron no tenkai: Sogyo kara JR made 120-nen [Development of railway policy theory: 120 years from foundation to JR] (pp. 191-246). Tokyo, Japan: Hakuto-Shobo (in Japanese).

Ishido, M. (1999). JR Honshu 3-sha kabushiki no baikyaku to jojo: Kokutetsu kaikaku ni okeru igi to kadai (zenpen, kohen) [Sale and listing of shares in three JR Honshu companies: Significance and issues in JNR reform (Part 1 and Part 2)]. Transportation and Economy, 59(4), 22-28 (Part 1); 59(5), 44-50 (Part 2) (in Japanese).

Kikuchi, H. (2016). Social shaping of technological trajectories of Shinkansen. Annals of Business Administrative Science, 15, 175186. doi: $10.7880 /$ abas.0160605a

Kikuchi, H. (2018). The legitimacy acquisition process of Shinkansen speeding up. Annals of Business Administrative Science, 17, 133143. doi: $10.7880 /$ abas.0180509a

Nakamura, M. (2019). Kindainihon tetsudo kaikei-shi: Kokuyu tetsudo wo chushin to shite [History of modern Japanese railway accounting: Focusing on national railways]. Tokyo, Japan: Dobunkan (in Japanese).

Nakanishi, K. (1988). Suitai-ki no Kokutetsu: 1964-1987 [Japanese National Railways in Decline: 1964-1987]. In Transportation Economics Research Center (Ed.), Tetsudo seisaku-ron no tenkai: Sogyo kara JR made 120-nen [Development of railway policy theory: 120 years from foundation to JR] (pp. 247-411). Tokyo, Japan: Hakuto-Shobo (in Japanese). 
Nihon Kokuyu Tetsudo (1973). Nihon Kokuyu Tetsudo hyakunenshi [Centennial history of the Japanese National Railways] (Vol. 12). Tokyo, Japan: Koutsu Kyouryoku Kai (in Japanese).

Takahashi, N. (2000). Tetsudo keiei to shikin chotatsu [Railway management and financing schemes]. Tokyo, Japan: Yuhikaku (in Japanese). doi: 10.15083/00074200

Takahashi, N. (2001). Toward audit of business. Government Auditing Review, 8, 3-19. Retrieved from http://report.jbaudit.go.jp/ english_exchange/volume8/e08d01.pdf

Takahashi, N. (2019, October). JNR's financing schemes and bankruptcy. Paper presented at ABAS Conference 2019 Autumn, University of Tokyo, Japan. 